\title{
Pasture renewal on Bay of Plenty and Waikato dairy farms: impacts on pasture production and invertebrate populations post-establishment
}

\author{
K.N. TOZER, G.M. RENNIE, W.M. KING, N. R. MAPP, N.L. BELL, C.A. CAMERON and T.M. EDEN \\ AgResearch, Ruakura Research Centre, Private Bag 3123, Hamilton, New Zealand
}

Katherine.tozer@agresearch.co.nz

\begin{abstract}
The impact of renewal on pasture production was determined by monitoring renewed and unrenewed pastures on five farms in each of Bay of Plenty and Waikato for 3 years, excluding the year after sowing (establishment). Renewed pastures produced an additional $1.5 \mathrm{t}$ dry matter (DM)/ha averaged over both regions in the second year after establishment and $1.9 \mathrm{t}$ $\mathrm{DM} /$ ha in each of the third and fourth years. Renewed pastures also had greater clover DM content in spring and summer and lower broadleaf weed DM content in winter. Perennial ryegrass tiller densities were similar in renewed and unrenewed pastures in both regions. There were fewer white-fringed weevil, black beetle and total nematodes in renewed pastures on at least one of the sampling times. It was concluded that higher clover content, fewer weeds, and fewer insect pests contributed to greater DM production in renewed pastures.
\end{abstract}

Keywords: Pasture renewal; dairy pastures; pasture persistence; DM production; regrassing

\section{Introduction}

Pasture renewal can result in increased farm performance by improving pasture dry matter yield and quality (Glassey et al. 2010). In addition, as part of the renewal process, weed and insect pest populations can be suppressed by use of herbicides and pesticides, and the physical disruption of the soil and removal of host plants such as summer-growing grasses that black beetle (Heteronychus arator) feed on (Bell et al. 2006).

Many farmers are concerned, however, that the possible benefits of pasture renewal are not being realised on-farm. Poor persistence of newly sown species and rapid reversion to a poorly performing, weed- and insect pest-affected pasture are cited as major issues (Bewsell et al. 2008; Kelly \& Smith 2011; Tozer et al. 2011b). This is particularly true in Bay of Plenty (BoP), Waikato and other northern North Island areas, where pastures have been subjected to recent dry summers with high insect pest and weed loads (e.g., Bell et al. 2011; Tozer et al. 2010a; Tozer et al. 2010b). Farmers are also concerned that the claimed dry matter yield gains of new cultivars are unrealistic and do not correlate well with those achieved on commercial farms. This has led to a lack of trust in commercially supplied promotional material regarding the benefits of pasture renewal (Bewsell et al. 2008).

To determine the impact of renewal on pasture production on-farm, a project was initiated to compare the dry matter production and botanical composition of renewed and unrenewed dairy pastures in BoP and Waikato. This paper reports on three years of seasonal and annual production (post-establishment year), botanical composition, grass tiller density and invertebrate population data.

\section{Methods}

A total of 24 pastures were selected from five farms in Waikato and five farms in Bay of Plenty (Figure 1). Waikato farms were located between Tokoroa and Gordonton while those in Bay of Plenty were situated on the Edgecumbe plains. Two or three pastures were chosen on each farm, resulting in seven renewed pastures and five unrenewed pastures in each region. The chosen pastures were similar in soil type and previous management history, and were typical of older pastures on the selected farms. The pasture chosen for renewal was randomly selected by the farmer, except on two Waikato farms where the lower performing pasture was chosen. Overall, this comparison provides a contrast between a new pasture and a "typical old" pasture (mostly more than 10 years old). On nine farms, the pastures selected for renewal were sown with perennial ryegrass (Lolium perenne) containing a novel endophyte (AR37, AR1 or NEA2) and white clover (Trifolium repens), with proprietary seed treatments recommended by the seed suppliers. The unrenewed pastures contained unknown cultivars with standard endophyte, except for one pasture with AR1. The tenth farm compared renewed pastures sown with tall fescue (Festuca arundinacea syn. Schedonorus phoenix) with MaxP endophyte, to unrenewed pastures of older endophyte-free tall fescue. The process of renewal included both grass-to-grass and crop-to-grass sequences, an array of ryegrass cultivars (diploid and tetraploid) and different renewal years (Table 1).

Growth was assessed in all pastures by harvesting herbage from three grazing exclusion cages (quadrat 


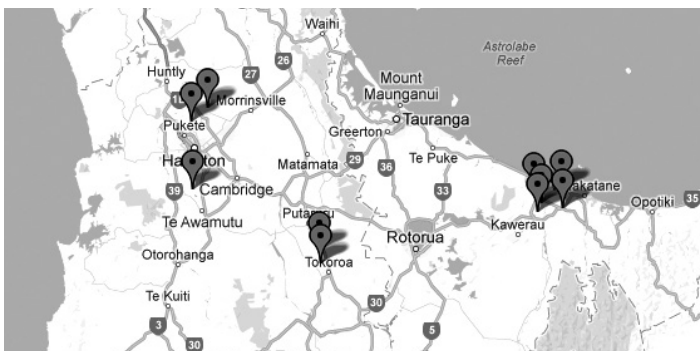

Figure 1 Location of the five farms in each of Waikato and Bay of Plenty where a total of 24 renewed and unrenewed pastures were selected for monitoring.

size $0.25 \times 0.50 \mathrm{~m})$ to "grazing height" $(\mathrm{ca} .2 \mathrm{~cm})$, using an electric shearing hand-piece. Harvests occurred at 4 to 8 week intervals depending on the season. Pasture cages were moved to a new randomly selected position after each harvest.

Approximately $40 \mathrm{~g}$ of the harvested material was sub-sampled and sorted into grasses (sown and unsown), clovers (Trifolium spp.) and broadleaf weeds to determine botanical composition. All vegetation was then oven-dried $\left(>24 \mathrm{~h}\right.$ at $\left.65^{\circ} \mathrm{C}\right)$ and the oven dry weights scaled-up to estimate pasture herbage production ( $\mathrm{t}$ dry matter (DM)/ha). Climate data (rainfall, temperature, solar radiation) for each farm were obtained from NIWA's virtual climate station database (Tait et al. 2006; Tait \& Woods 2007).

Tiller density of sown grasses and all other grasses was assessed in mid-spring (late September/October) 2011 and 2012 and in autumn (late April/May) 2012. Twenty soil cores were removed at regular intervals along a $30 \mathrm{~m}$ transect adjacent to the pasture cages. A $5 \mathrm{~cm}$ diameter core was used for the spring 2011 sampling but this was changed to a $10 \mathrm{~cm}$ core for the remainder to increase the number of plants sampled.

The presence of endophyte in perennial ryegrass plants was assessed each November. A healthy vegetative main tiller was cut to ground level from 100 plants sampled at regular intervals along a diagonal transect across each pasture. Collected tillers were recut and pressed onto $0.45 \mu \mathrm{m}$ nitrocellulose blotting paper (Protran BA45, Thermo Fisher Scientific) for 2-3 seconds within 24 hours of sampling. Blotting sheets were processed using the tissue print immunoassay method of Hahn et al. (2003) to determine the endophyte infection frequency.

Soil fertility was assessed in spring (September/ October) from a minimum of 25 cores sampled to 7.5 $\mathrm{cm}$ depth along a $30 \mathrm{~m}$ transect. Soil was analysed by a commercial testing laboratory for standard pasture nutrients ( $\mathrm{pH}$, Olsen $\mathrm{P}, \mathrm{K}, \mathrm{S}\left(\mathrm{SO}_{4}\right), \mathrm{Mg}, \mathrm{Ca}$ and $\mathrm{Na}$ ).

In February each year, soil-dwelling invertebrate populations were assessed in each pasture by removing 10 spade-squares $(20 \times 20 \mathrm{~cm}$ to $20 \mathrm{~cm}$ depth $)$ at $2 \mathrm{~m}$ intervals along a $30 \mathrm{~m}$ transect in the vicinity of pasture cages. Soil from each spade-square was hand crumbled and all visible insects and earthworms were identified and counted. Foliage invertebrates were collected using a modified blower-vac from along a $30 \mathrm{~m}$ transect adjacent to the transect used to sample soil dwelling invertebrates, and were taken back to a laboratory for enumeration of clover root weevil (Sitona lepidus) and Argentine stem weevil (Listronotus bonariensis) adults. For nematode assessments, one soil core $(2.5 \mathrm{~cm}$ diameter $\times 7.5 \mathrm{~cm}$ depth) was removed adjacent to each spade-square. Cores were bulked within each pasture and hand crumbled in a laboratory. A $100 \mathrm{~g}$ subsample

Table 1 Year of renewal, renewal sequence (crop-to-grass or grass-to-grass) and cultivars sown in 14 renewed pastures which were monitored on five farms in each of Waikato and Bay of Plenty.

\begin{tabular}{lllll}
\hline Region & Farm & Year of renewal & Renewal sequence & Cultivar sown \\
\hline Waikato & Farm 1 & 2009 & Grass-to-grass & Extreme AR37 \\
& Farm 2 & 2007 & Grass-to-grass & Arrow, AR1 \\
& 2008 & Grass-to-grass & Bealey/Arrow, NEA2/AR1 \\
& Farm 3 & 2009 & Crop & Arrow/Alto AR1 \\
& Farm 4 & 2010 & Crop & Alto AR37 \\
& Farm 5 & 2007 & Crop & Tall fescue Max P \\
& & Crop & Tall fescue Max P \\
\hline Bay of Plenty & Farm 1 & 2009 & Grass-to-grass & Bealey NEA2 \\
& & Grass-to-grass & Bealey NEA2 \\
& Farm 2 & 2008 & Crop & Bealey NEA2 \\
& & Grass to grass & Bealey NEA2 irrigated \\
& Farm 3 & 2009 & Grass to grass & Commando AR37 \\
& Farm 4 & 2008 & Crop & Extreme AR37 \\
& Farm 5 & 2008 & Crop & Bealey NEA2
\end{tabular}



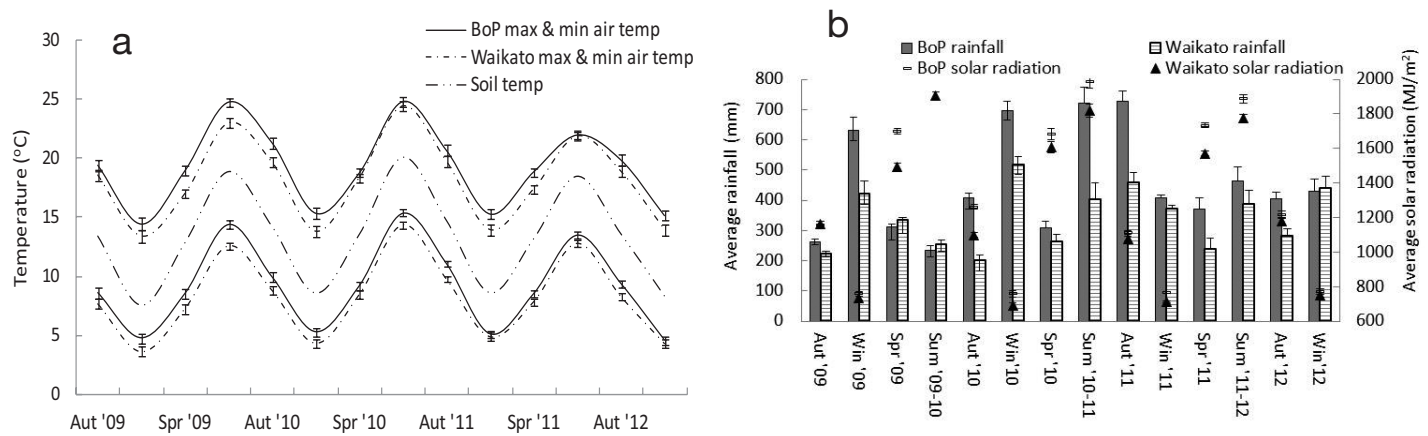

Figure 2 a): Average seasonal maximum and minimum air temperatures $\left({ }^{\circ} \mathrm{C}\right)$ in Bay of Plenty $(\mathrm{BoP})$ and Waikato and seasonal soil temperature $\left({ }^{\circ} \mathrm{C}\right)$ averaged over both districts, and: b) average seasonal rainfall $(\mathrm{mm})$ and solar radiation $\left(\mathrm{MJ} / \mathrm{m}^{2}\right)$ in $\mathrm{BoP}$ and Waikato. Data are based on the nearest NIWA virtual climate station to the surveyed pastures. Standard error bars are shown.

was used to extract nematodes over three days using the modified Whitehead \& Hemming tray method described by Bell \& Watson (2001). The total number of nematodes was counted under a microscope at 40-80 $\times$ magnification.

Data were analysed using Residual Maximum Likelihood (REML) (Patterson \& Thompson 1971) in GenStat, 13th edition (VSN International 2010) to produce means allowing for the unbalanced design arising from the varied number of pastures per farm. The REML fixed effects were district (region), renewed or unrenewed and their interaction. The REML random effects were site (farm) and site•pasture (pasture within farm). Analyses were undertaken for each individual year and also over 3 years. Since the number of pastures sampled varied between farms, the predicted means for seasons do not sum exactly to the predicted total means (Tables 2, 4).

Table 2 Seasonal and total annual dry matter production $(\mathrm{kg} \mathrm{DM} / \mathrm{ha})$ in renewed and unrenewed dairy pastures from September 2009-August 2012. Dry matter data are means of Waikato and Bay of Plenty (BoP) pastures. Renewed pastures were 1-2 years old when measurements began. Summer: December-February; autumn: March-May; winter: June-August; spring: September-November. ${ }^{*}: \mathrm{P}<0.05 ;{ }^{* *} \mathrm{P}<0.01$; ${ }^{* \star} \mathrm{P}<0.001$. SED: standard error of difference.

\begin{tabular}{|c|c|c|c|c|c|c|}
\hline \multirow[b]{2}{*}{ Season } & \multicolumn{3}{|c|}{ Renewed } & \multicolumn{3}{|c|}{ Region } \\
\hline & Yes & No & SED & BOP & Waikato & SED \\
\hline \multicolumn{7}{|l|}{ 2009-2010 } \\
\hline Spring & 4.4 & 4.3 & 0.27 & 4.4 & 4.3 & 0.43 \\
\hline Summer & 6.3 & 5.7 & 0.33 & 6.2 & 5.8 & 0.83 \\
\hline Autumn & 2.8 & 2.7 & 0.26 & 3.4 & 2.1 & 0.68 \\
\hline Winter & 2.8 & 2.1 & $0.11^{1}$ & 2.7 & 2.1 & 0.37 \\
\hline Annual & 16.2 & 14.8 & $0.39^{* *}$ & 16.7 & 14.3 & 2.06 \\
\hline \multicolumn{7}{|l|}{ 2010-2011 } \\
\hline Spring & 5.9 & 5.3 & 0.35 & 6.4 & 4.8 & 0.90 \\
\hline Summer & 6.5 & 5.4 & $0.35^{\star *}$ & 6.9 & 5.1 & $0.54^{\star *}$ \\
\hline Autumn & 3.2 & 3.0 & 0.30 & 2.9 & 3.2 & 0.58 \\
\hline Winter & 2.5 & 2.4 & 0.40 & 2.7 & 2.2 & 0.36 \\
\hline Annual & 18.0 & 16.1 & $0.60^{\text {** }}$ & 18.9 & 15.2 & 1.89 \\
\hline \multicolumn{7}{|l|}{$2011-2012$} \\
\hline Spring & 6.2 & 5.5 & $0.29^{\star}$ & 5.7 & 6.0 & 0.43 \\
\hline Summer & 4.8 & 4.4 & 0.26 & 5.5 & 3.7 & 0.78 \\
\hline Autumn & 4.2 & 3.8 & 0.34 & 4.0 & 4.1 & 0.70 \\
\hline Winter & 2.7 & 2.3 & 0.20 & 2.8 & 2.3 & 0.41 \\
\hline Annual & 17.9 & 16.0 & $0.74^{*}$ & 17.8 & 16.0 & 2.06 \\
\hline
\end{tabular}

${ }^{1}$ Significantly greater winter DM production in renewed than unrenewed pastures in BoP only, $\mathrm{P}<0.05$.

Note: Since the number of pastures vary for each farm, the predicted means for season do not sum exactly to the predicted annual means. 


\section{Results}

\section{Impact of renewal}

Pasture renewal significantly improved total annual DM production (Table 2). Averaged over both regions, an additional $1.5 \mathrm{t} \mathrm{DM} / \mathrm{ha}$ was produced in renewed pastures in the second year after establishment and an additional $1.9 \mathrm{t} \mathrm{DM} / \mathrm{ha}$ in each of the third and fourth years.

There were significant differences in seasonal production too: dry matter production was significantly greater in renewed pastures in winter 2010 in BoP, and in summer 2010/2011 and spring 2011 in both regions (Table 2).

With respect to the sown grass component of the sward, there was no significant difference between renewed and unrenewed pastures in any of the individual years or when summed over the three years (Table 3 and 4).

When compared to unrenewed pastures, clover content was greater in renewed pastures in 2 of the 3 years, depending on the region (Table 3 ). When summed over the 3-year period, total clover content, and clover content in spring and summer, was greater in renewed than unrenewed pastures (Table 4).

When compared to unrenewed pastures, broadleaf weed content was lower in renewed pastures in 1 of 3 years (Table 3 ). Broadleaf weed content varied by season and was lower in winter $(0.2 \mathrm{vs} 0.5 \mathrm{tDM} / \mathrm{ha}$ when summed over the 3 years, $\mathrm{P}=0.001$; data not shown).

There were no significant differences between renewed and unrenewed pastures with respect to unsown grass content (in individual seasons or years or when summed over the 3 years, data not shown).

Perennial ryegrass tiller densities were similar in renewed and unrenewed pastures in spring 2011 (averaging 4378/ $\mathrm{m}^{2}$ ), autumn $2012\left(3917 / \mathrm{m}^{2}\right)$ and spring $2012\left(3999 / \mathrm{m}^{2}\right)$. The tiller density of other grasses (e.g. Poa annua, Paspalum dilatatum) was also similar in renewed and unrenewed pastures in spring 2011 (averaging $\left.1660 / \mathrm{m}^{2}\right)$, autumn $2012\left(1605 / \mathrm{m}^{2}\right)$ and spring $2012\left(1854 / \mathrm{m}^{2}\right)$.

Endophyte infection levels in pastures sown with perennial ryegrass were similar in renewed and unrenewed pastures in 2010 (averaging 89\%), 2011 $(86 \%)$ and $2012(81 \%)$. Of the two pastures renewed with novel endophyte tall fescue, one had a high infection frequency $(98 \%, 98 \%$ and $92 \%)$ and one was found to have a very low infection frequency $(9 \%, 14 \%$ and $8 \%$ ). The low level of endophyte infection was comparable to the unrenewed tall fescue pasture which had been sown with nil endophyte and was found to have $6 \%, 6 \%$ and $2 \%$ infection over the three annual surveys.

Pasture renewal also had an impact on invertebrate pest populations. The number of black beetle in the soil in $2010\left(12 \mathrm{vs} .38 / \mathrm{m}^{2}\right)$, white fringed weevil (Naupactus leucoloma) in the soil in 2011, total insects in 2010, and total nematodes in 2011 were lower in renewed than unrenewed pastures (Table 5). Foliar insect populations were similar in renewed and unrenewed pastures.

Soil nutrient levels were not significantly different in renewed and unrenewed pastures in spring 2011 and 2012, averaging $\mathrm{pH}=6.1,6.0 ; \mathrm{Ca}=8.0,8.9 \mathrm{MAF}$ QT; Olsen $\mathrm{P}=68,56 \mu \mathrm{g} / \mathrm{ml} ; \mathrm{K}=9,9$ MAF QT; $\mathrm{S}(\mathrm{SO} 4)=$ 26, 16 ppm; $\mathrm{Mg}=27,24 \mathrm{MAF} \mathrm{QT}$; and $\mathrm{Na}=8,7 \mathrm{MAF}$ QT; in 2011 and 2012 respectively.

\section{Impact of region}

For each region, the DM production differences between renewed and unrenewed pastures were statistically significant for all 3 years in the BoP but only for 2 years in the Waikato. The overall result for the 2010/11 season was driven by a very large difference in the BoP (an additional 3.7 t DM/ha) and a very small difference in Waikato (0.1 t DM/ha).

Seasonal dry matter production varied between regions in only one season: in summer 2010/11, pasture production was higher in the $\mathrm{BoP}$ (Table 2). There were no differences between regions in perennial ryegrass and other grass tiller densities or endophyte infection levels in any of the years assessed.

Pest densities were similar across regions in 2010 and in 2011. In 2012, densities of a number of taxa were higher in the Waikato: black beetle (12 vs. $4 / \mathrm{m}^{2}$, $\mathrm{P}<0.05$ ), white fringed weevil ( 8 vs. $1 / \mathrm{m}^{2}, \mathrm{P}<0.05$ ), clover root weevil (63 vs. $29 / \mathrm{m}^{2}, \mathrm{P}<0.05$ ), total soil insects $\left(126\right.$ vs. $\left.52 / \mathrm{m}^{2}, \mathrm{P}<0.05\right)$ and foliar clover root

Table 3 Sown grass, clover and broadleaf weed content (t DM/ha) in renewed and unrenewed dairy pastures in 2010, 2011 and 2012. Production data are means of Waikato and Bay of Plenty pastures. *: P<0.05. SED: standard error of difference.

\begin{tabular}{|c|c|c|c|c|c|c|c|c|c|}
\hline \multirow[b]{3}{*}{ Annual production } & \multicolumn{3}{|c|}{$2009-2010$} & \multicolumn{3}{|c|}{$2010-2011$} & \multicolumn{3}{|c|}{ 2011-2012 } \\
\hline & \multicolumn{2}{|c|}{ Renewed } & \multirow[b]{2}{*}{ SED } & \multicolumn{2}{|c|}{ Renewed } & \multirow[b]{2}{*}{ SED } & \multicolumn{2}{|c|}{ Renewed } & \multirow[b]{2}{*}{ SED } \\
\hline & Yes & No & & Yes & No & & Yes & No & \\
\hline Sown grass & 10.9 & 9.5 & 0.94 & 13.8 & 12.3 & 0.85 & 11.8 & 11.1 & 0.88 \\
\hline Clover & 1.6 & 0.8 & $0.38^{1}$ & 1.1 & 0.6 & $0.22^{*}$ & 2.3 & 1.5 & 0.42 \\
\hline Broadleaf weed & 1.9 & 2.9 & 0.62 & 0.8 & 1.4 & $0.23^{\star}$ & 1.4 & 1.4 & 0.30 \\
\hline
\end{tabular}

${ }^{1}$ Significantly greater annual clover DM production in renewed than unrenewed pastures in Bay of Plenty only, $\mathrm{P}<0.05$. 
weevil ( 3 vs. $\left.1 / \mathrm{m}^{2}, \mathrm{P}<0.01\right)$.

Of the soil nutrients, Ca levels differed between regions ( 9 vs. 7 in 2011 and 11 vs. 7 in 2012 for Waikato and $\mathrm{BoP}$ respectively, $\mathrm{P}<0.05$ ).

$\mathrm{BoP}$ sites were often warmer (Figure $2 \mathrm{a}, \mathrm{P}<0.05$ ) and often received more solar radiation and rainfall $(\mathrm{P}<0.05$, Figure $2 b$ ) than did the Waikato sites overall.

\section{Discussion}

Pasture renewal significantly improved total annual DM production. Similar results were noted by Glassey et al. (2010) in a research dairy farmlet study in Waikato where the renewed pastures, most of which were less than 3 years old, produced an additional $2.1 \mathrm{t} \mathrm{DM} / \mathrm{ha}$ when compared to a farmlet in which pastures were at least 10 years old. In that study, as in this one, the greater total annual DM production was due to greater DM production during different seasons in different years although there was a consistent effect of greater DM production in renewed pastures during summer. In the northern North Island, additional DM production in summer is of higher value as there is a risk of feed supply shortage due to drought (Macdonald et al. 2011).

Tiller numbers rapidly reached a similar density in renewed and unrenewed pastures. The similar tiller densities but greater total DM production in renewed pastures would suggest that perennial ryegrass plants performed better in renewed pastures. There was a trend towards greater sown grass DM production in renewed pastures but this was not significant on an annual or seasonal basis when summed over the 3 years.

DM production benefits from renewed pastures were unlikely to be due to differences in soil nutrients or endophyte infection levels which were similar in renewed and unrenewed pastures. Based on the data collected during this survey, there are three factors which contributed to improved new pasture performance: insect pressure, weed burden and clover content.

The first key difference between the renewed and unrenewed pastures was insect pest pressure, particularly black beetle abundance. There was a trend towards fewer black beetle in renewed than unrenewed pastures in all four February samplings, with the difference being significant in 1 of the 4 years. This is during a time of year when abiotic plant stress (viz. drought) is greatest and late instar larvae are exerting their greatest impact on grass root growth (Bell et al. 2011). Black beetle feed exclusively on grasses and determination of the population level at which they cause significant damage to pastures is confounded by grass type and abiotic stress. Populations of 20-40 beetles $/ \mathrm{m}^{2}$ are considered damaging (see Bell et al. 2011) with the lower level likely to be causing damage during dry, hot conditions and the upper level during more optimal plant growing conditions. In the current study it appears black beetle populations at the levels observed (mean $6-42 / \mathrm{m}^{2}$ )

Table 4 Dry matter production of pasture components (t DM/ha) in renewed and unrenewed dairy pastures, summed over the 3 year period from 2009-2012. Dry matter data are means of Waikato and Bay of Plenty (BoP) pastures. *: $\mathrm{P}<0.05$; ** $P<0.01 ;{ }^{* \star} P<0.001$. SED: standard error of difference.

\begin{tabular}{|c|c|c|c|c|}
\hline \multirow[t]{2}{*}{ Component } & \multirow[b]{2}{*}{ Season } & \multicolumn{2}{|c|}{ Renewed } & \multirow[b]{2}{*}{ SED } \\
\hline & & Yes & No & \\
\hline \multirow[t]{5}{*}{ Sown grass } & Spring & 11.9 & 10.9 & 0.81 \\
\hline & Summer & 11.1 & 10.1 & 0.81 \\
\hline & Autumn & 7.5 & 6.5 & 0.64 \\
\hline & Winter & 6.0 & 5.4 & 0.35 \\
\hline & Total & 36.4 & 32.9 & 2.13 \\
\hline \multirow[t]{5}{*}{ Clover } & Spring & 1.6 & 1.0 & $0.26^{\star}$ \\
\hline & Summer & 1.8 & 1.0 & $0.31^{*}$ \\
\hline & Autumn & 0.9 & 0.6 & 0.23 \\
\hline & Winter & 0.5 & 0.3 & 0.11 \\
\hline & Total & 4.9 & 2.9 & $0.81^{*}$ \\
\hline \multirow[t]{5}{*}{ All vegetation } & Spring & 16.4 & 15.1 & 0.64 \\
\hline & Summer & 17.6 & 15.5 & $0.64^{\star *}$ \\
\hline & Autumn & 10.2 & 9.5 & 0.46 \\
\hline & Winter & 7.9 & 6.8 & $0.31^{1}$ \\
\hline & Total & 52.0 & 46.8 & $1.18^{* * *}$ \\
\hline
\end{tabular}

${ }^{1}$ Significantly greater DM production in renewed than unrenewed pastures in BoP only, $\mathrm{P}<0.05$.

Note: Since the number of paddocks vary for a farm, the predicted means for season do not sum exactly to the predicted annual means. 
may not have caused significant loss of ryegrass tillers but have likely contributed to the reduction in DM production, particularly of sown grasses, via a reduction in root mass leading to plant stress and reduced growth rates (Bell et al. 2011). For example, the significantly greater black beetle populations in unrenewed (38/ $\left.\mathrm{m}^{2}\right)$ than renewed $\left(12 / \mathrm{m}^{2}\right)$ pastures in February 2010 were associated with a $17 \%$ reduction in sown grass DM yield during summer in unrenewed compared to renewed pastures across both districts. Root feeding by pest insects and nematodes in the soil can cause large reductions in plant growth and survival (Zydenbos et al. 2011). Physical disturbance and removal of host plants during the renewal process can help to break the pest cycle (Bell et al. 2006). Pest insects and nematodes were sometimes higher in Waikato than BoP; this may have contributed to the lower DM production figures in Waikato than BoP in some seasons/years.

The second key difference observed was a greater broadleaf weed burden in the unrenewed pastures. This increases competition for water, nutrients and light, which may have reduced growth and DM production of the potentially more productive sown species (Tozer et al. 2011a). Thirdly, greater legume content in the renewed pastures is likely to increase nitrogen fixation and plant available $\mathrm{N}$, thereby increasing pasture growth.

Increases in clover content and reductions in weed content would also increase pasture quality and the efficiency of utilisation of metabolisable energy for animal growth (Nicol \& Edwards 2011). Animal production benefits from grazing renewed pastures may be therefore somewhat greater than indicated by DM alone.

Results from this trial are inconsistent with results from irrigated dairy farms in Canterbury and North
Otago, where there was no difference between renewed and unrenewed pastures in DM production (Taylor et al. 2012). Two key reasons for the difference between findings of Taylor et al. (2012) and those presented here are that firstly, the Waikato/BoP study did not incorporate $\mathrm{DM}$ production during the establishment year (which may be much less in the renewed than unrenewed pastures), and secondly, the lack of irrigation in Waikato and BoP pastures. The summer/autumn drought frequently experienced in these northern regions, coupled with high black beetle and other pest populations, contributes to sown species mortality, weed ingress and loss of DM production. Renewing pastures interrupts this decline and, based on these results, lifts productivity for at least several years after sowing. Continued monitoring of the BoP and Waikato pastures will determine the length of time for which these yield gains persist.

In conclusion, pasture renewal resulted in significant DM production benefits in both $\mathrm{BoP}$ and Waikato, though the benefits were somewhat less pronounced in Waikato. There were advantages in improving pasture composition (and hence quality), with a higher content of sown species and fewer broadleaf weeds in renewed pastures as well as fewer insect pests. The similar tiller densities of sown species in renewed and unrenewed pastures suggested that the sown species populations quickly reached an equilibrium tiller density, although no information on plant size was recorded. Given the greater dry matter production of renewed pastures, results suggested reductions in pest and/or weed burdens were at least in part responsible. However, for DM production benefits to be maintained, tiller populations must also be maintained. Further monitoring of these

Table 5 Density of soil and foliar dwelling insects and earthworms in renewed and unrenewed dairy pastures in February 2009, 2010, 2011 and 2012. Insect data are means of Waikato and BoP pastures. ${ }^{*}: P<0.05$; ${ }^{* *} P<0.01$; ${ }^{* \star} P<0.001$. SED: standard error of difference.

\begin{tabular}{|c|c|c|c|c|c|c|c|c|c|c|c|c|}
\hline \multirow[b]{3}{*}{ Density (numbers $\left./ \mathrm{m}^{2}\right)^{1}$} & \multicolumn{3}{|c|}{2009} & \multicolumn{3}{|c|}{2010} & \multicolumn{3}{|c|}{2011} & \multicolumn{3}{|c|}{2012} \\
\hline & \multicolumn{2}{|c|}{ Renewed } & \multirow[b]{2}{*}{ SED } & \multicolumn{2}{|c|}{ Renewed } & \multirow[b]{2}{*}{ SED } & \multicolumn{2}{|c|}{ Renewed } & \multirow[b]{2}{*}{ SED } & \multicolumn{2}{|c|}{ Renewed } & \multirow[b]{2}{*}{ SED } \\
\hline & Yes & No & & Yes & No & & Yes & No & & Yes & No & \\
\hline \multicolumn{13}{|l|}{ Soil dwelling } \\
\hline Black beetle & 26 & 42 & 14.1 & 12 & 38 & $6.0^{\star \star \star}$ & 9 & 12 & 4.8 & 6 & 10 & 3.5 \\
\hline White fringed weevil & 7 & 10 & 6.0 & 3 & 44 & 20.0 & 1 & 13 & $3.5^{\star \star}$ & 3 & 7 & 2.3 \\
\hline Earthworms & 159 & 201 & 44.9 & 156 & 235 & 39.0 & 213 & 165 & 93.5 & 223 & 254 & 45.5 \\
\hline Clover root weevil & 20 & 12 & 11.5 & 11 & 10 & 5.5 & 6 & 4 & 3.1 & 45 & 46 & 10.5 \\
\hline Total insects & 95 & 100 & 33.1 & 61 & 155 & $31.4^{*}$ & 44 & 67 & 12.1 & 87 & 90 & 20.0 \\
\hline Total nematodes & 115 & 116 & 37.7 & 55 & 55 & 5.2 & 83 & 118 & $12.8^{\star}$ & 97 & 83 & 17.2 \\
\hline \multicolumn{13}{|l|}{ Foliar dwelling } \\
\hline Clover root weevil & - & - & & 4 & 3 & 0.8 & 1 & 1 & 0.6 & 3 & 2 & 0.8 \\
\hline Argentine stem weevil & - & - & & 34 & 20 & 10.8 & 21 & 11 & 6.6 & 5 & 4 & 3.3 \\
\hline
\end{tabular}

${ }^{1}$ Nematode abundance is per $\mathrm{g}$ dry soil. 
pastures will enable us to determine the extent to which renewed pastures persist.

\section{ACKNOWLEDGEMENTS}

Thanks to DairyNZ, and Ministry for Primary Industries (through Sustainable Farming Fund: SFF 08-019, 11089, 11-035) for providing funding for this BOP Focus on Dairy initiated project. We are also grateful for the additional support of Ballance Agrinutrients, Agricom, PGGW Seeds, Agriseeds, BoP Regional Council and Waikato Regional Council. Many thanks to farmers in $\mathrm{BoP}$ and Waikato for making their views known and their paddocks available. We thank Linda Trolove and Lee Aalders of AgResearch for their assistance with pasture and nematode analyses respectively and the referees for their extremely helpful comments on the manuscript.

\section{REFERENCES}

Bell, N.L.; Hardwick, S.; Eerens, J.P.J.; James, T.K. 2006. Managing biological succession in intensive pastoral ecosystems for improved production and sustainability. New Zealand Plant Protection 59: 271-280.

Bell, N.L.; Townsend, R.J.; Popay, A.I.; Mercer, C.F.; Jackson, T.A. 2011. Black beetle: lessons from the past and options for the future. Pasture Persistence Symposium. Grassland Research and Practice Series 15: 119-124.

Bell, N.L.; Watson, R.N. 2001. Optimising the Whitehead and Hemming tray method to extract plant parasitic and other nematodes from two soils under pasture. Nematology 3: 179-185.

Bewsell, D.; Botha, N.; Brown, M.; Fraser, T.; Wilson, J. 2008. Understanding pasture renewal in New Zealand. Report on market research for the Pasture Renewal Charitable Trust. 75pp.

Glassey, C.B.; Roach, C.G.; Strahan, M.R.; McClean, N. 2010. Dry matter yield, pasture quality and profit on two Waikato dairy farms after pasture renewal. Proceedings of the New Zealand Grassland Association 72: 91-96.

Hahn, H.; Huth, W.; Schöberlein, W.; Diepenbrock, W. 2003. Detection of endophytic fungi in Festuca spp. by means of tissue print immunoassay. Plant Breeding 122: 217-222.

Kelly, S.; Smith, E. 2011. Pasture renewal in the Waikato and Bay of Plenty regions: An overview of farmer practice, experience and attitudes. Pasture Persistence - Grassland Research and Practice Series 15: 21-24.
Macdonald, K.A.; Matthew, C.; Glassey, C.B.; McLean, N. 2011. Dairy farm systems to aid persistence. Pasture Persistence - Grassland Research and Practice Series 15: 199-210.

Nicol, A.M.; Edwards, G.R. 2011. Why is clover better than ryegrass? Proceedings of the New Zealand Society of Animal Production 71: 71-78.

Patterson, H.D.; Thompson, R. 1971. Recovery of interblock information when block sizes are unequal. Biometrika 58: 545-554.

Tait, A.; Henderson, R.; Turner, R.; Zheng, Z. 2006. Thin plate smoothing interpolation of daily rainfall for New Zealand using a climatological rainfall surface. International Journal of Climatology 26: 2097-2115.

Tait, A.; Woods, R. 2007. Spatial interpolation of daily potential evapotranspiration for New Zealand using a spline model. Journal of Hydrometeorology 8: 430-438.

Taylor, A.L.; Fraser, T.J.; King, W.M. 2012. Performance of new dairy pastures. Proceedings of the New Zealand Grassland Association 74: 159-164.

Tozer, K.N.; Barker, G.M.; Cameron, C.A.; James, T.K. 2010a. Relationship between seedbank and aboveground botanical composition during spring. New Zealand Plant Protection 63: 90-95.

Tozer, K.N.; Barker, G.M.; Cameron, C.A.; Loick, N. 2010b. New Zealand dryland pastures: effects of sown pasture species diversity on the ingress of unsown species. pp. 398-401. In: 17th Australasian Weeds Conference. Christchurch, New Zealand.

Tozer, K.N.; Bourdot, G.W.; Edwards, G.R. 2011a. What processes lead to poor pasture persistence and weed ingress? Pasture Persistence Symposium. Grasslands Research and Practice Series 15: 129-137.

Tozer, K.N.; Cameron, C.A.; Thom, E.R. 2011b. Pasture persistence: farmer observations and field measurements. Pasture Persistence Symposium. Grasslands Research and Practice Series 15: 25-30. Zydenbos, S.M.; Barratt, B.I.P.; Bell, N.L.; Ferguson, C.M.; Gerard, P.J.; McNeill, M.R.; Phillips, C.B.; Townsend, R.J.; Jackson, T.A. 2011. The impact of insect pests on pasture persistence and their interrelationship with biotic and abiotic factors. Pasture Persistence Symposium. Grassland Research and Practice Series 15: 109-118. 
